\title{
IMPLIKASI HUKUM ATAS PUTUSAN MAHKAMAH KONSTITUSI NOMOR 25/PUU-XIV/2016 TERHADAP PEMBERANTASAN TINDAK PIDANA KORUPSI
}

\author{
Dadin E. Saputra \\ Fakultas Hukum Universitas Islam Kalimantan \\ Muhammad Arsyad al-Banjari Banjarmasin \\ e-Mail: delawfirm30@gmail.com \\ Afif Khalid \\ Fakultas Hukum Universitas Islam Kalimantan \\ Muhammad Arsyad al-Banjari Banjarmasin
}

\begin{abstract}
Abstrak: Korupsi di Indonesia terus menunjukkan peningkatan dari tahun ke tahun. Baik dari jumlah kasus yang terjadi maupun jumlah kerugian keuangan negara. Kualitas tindak pidana korupsi yang dilakukan juga semakin sistematis dengan lingkup yang memasuki seluruh aspek kehidupan masyarakat. Oleh karena itu penulis tertarik melakukan penelitian ini dengan rumusan masalah yaitu bagaimana pertimbangan hukum Majelis Hakim Mahkamah Konstitusi dalam Putusan Mahkamah Konstitusi Nomor 25/PUU-XIV/2016 dan implikasi hukum apa yang dapat timbul terkait dengan proses penegakan hukum dan pemberantasan tindak pidana korupsi. Tujuan dalam penelitian ini adalah pertama, untuk mengetahui pertimbangan hukum Majelis Hakim Mahkamah Konstitusi dalam Putusan Mahkamah Konstitusi Nomor 25/PUU-XIV/2016. Kedua, untuk mengetahui implikasi hukum terkait dengan proses penegakan hukum dan pemberantasan tindak pidana korupsi. Jenis penelitian yang digunakan dalam penelitian ini adalah penelitian yuridis normatif, dengan metode pendekatan yuridis. Penelitian ini menggunakan metode kualitatif dan diuraikan secara deskriptif analitis. Adapun hasil dari penelitian ini yaitu: Putusan Mahkamah Konstitusi Nomor 25/PUU-XIV/2016 melahirkan ketidakpastian hukum yakni berkaitan dengan rumusan delik tindak pidana korupsi, dimana awalnya rumusan tindak pidana korupsi adalah delik formil menjadi delik materiil, sehingga penegak hukum harus dapat membuktikan berapa nilai kerugian keuangan negara atau perekonomian negara secara riil atau nyata (actual loss) bukan pada sudut pandang potensi nilai kerugian yang akan dialami (potential loss). Frasa kata "dapat" merugikan keuangan negara atau perekonomian negara antara pendekatan pidana sebagaimana dalam Undang-Undang Tindak Pidana Korupsi dengan pendekatan administratif sebagaimana dalam Undang-Undang Nomor 30 Tahun 2004 adalah 2 hal yang berbeda dan tidak mempunyai hubungan hukum.
\end{abstract}

Kata Kunci: Implikasi Hukum, Putusan MK Nomor 25/PUU-XIV/2016, Pemberantasan, Tindak Pidana Korupsi

Abstract: There is an increase in corruption level in Indonesia, both in the total number of cases and in the total amount of financial losses suffered by the state. There are even more systematic corruption which present in all aspect of social life. The main problem formulation would be focusing on the consideration upon the decision of the panel of judges of the Constitutional Court in its decision Number 25/PUU-XIV/2016 and its legal implication towards law enforcement process and corruption eradication. The objective of this research is, first, to understand the legal 
consideration of the panel of judges of constitutional court in the decision Number 25/PUUXIV/2016. As for the second objective, the researcher would like to be cognizant of the legal implication related with the law enforcement and corruption eradication process. In conducting the research, the researcher is using normative judicial research, with juridical approach as the method. This research is using qualitative method and in analytical-descriptive analysis. This research resulted in number of conclusions, per se, Constitutional Court decision Number 25/PUUXIV/2016 has created legal uncertainty related to the formulation of corruption; as corruption was material offense, whereof in the beginning was formal offense. Such circumstance obliges law enforcer to establish the ground on how much actual financial loss the state has suffered, not on potential financial loss. There is different, legally unrelated perspective in defining "could" as in "could inflict state financial loss or harm state economy" under criminal approach of Law on Corruption Eradication and under administrative approach of Law Number 30 Year 2004.

Keywords: Legal Implication, Constitutional Court Decision Number 25/PUU-XIV/2016, Eradication, Corruption.

\section{Pendahuluan}

Korupsi di Indonesia terus menunjukkan peningkatan dari tahun ke tahun. Baik dari jumlah kasus yang terjadi maupun jumlah kerugian keuangan negara. Kualitas tindak pidana korupsi yang dilakukan juga semakin sistematis dengan lingkup yang memasuki seluruh aspek kehidupan masyarakat. Kondisi tersebut menjadi salah satu faktor utama penghambat keberhasilan untuk mewujudkan masyarakat Indonesia yang adil dan makmur sebagaimana diamanatkan oleh Undang-Undang dalam memberantas korupsi. Korupsi juga semakin memperburuk citra pemerintah di mata masyarakat yang tercermin dalam bentuk ketidakpercayaan dan ketidakpatuhan masyarakat terhadap hukum, bila tidak ada perbaikan yang berarti, maka kondisi tersebut sangat membahayakan kelangsungan hidup bangsa. ${ }^{1}$

Menyadari kompleksnya permasalahan korupsi di tengah-tengah krisis multidimensional serta ancaman yang nyata yang pasti akan terjadi, yaitu dampak dari kejahatan ini. Maka, tindak pidana korupsi dapat dikategorikan sebagai permasalahan nasional yang harus dihadapi secara sungguh-sungguh melalui berbagai keseimbangan langkah yang tegas dan jelas dengan melibatkan semua potensi

\footnotetext{
1 Andi Hamzah, 1991, Korupsi Di Indonesia Masalah dan Pemecahannya, Jakarta: Gramedia Pustaka Utama, hlm.2.
} 
yang ada dalam masyarakat khususnya pemerintah dan aparat penegak hukum. ${ }^{2}$

Putusan Mahkamah Konstitusi Nomor 25/PUU-XIV/2016 telah menimbulkan berbagai macam pendapat baik yang pro maupun kontra, berkaitan dengan penanganan masalah pemberantasan tindak pidana korupsi. Permohonan atas judicial review ini diajukan terhadap ketentuan Pasal 2 ayat (1) dan Pasal 3 Undang-Undang Nomor 31 Tahun 1999 sebagaimana telah diubah dengan Undang-Undang Nomor 20 Tahun 2001 tentang Pemberantasan Tindak Pidana Korupsi tentang frasa "dapat merugikan keuangan negara" dan frasa "atau orang lain atau suatu korporasi".

Objek permohonan sebagaimana yang telah dimaksudkan diatas berdasarkan Pasal 2 ayat (1) UU Nomor 20 Tahun 2001 tentang

2 Evi Hartanti, 2005, Tindak Pidana Korupsi, Jakarta: Sinar Grafika, hlm.5. lihat juga Anwar Hafidzi, "Eksistensi Advokat Sebagai Profesi Terhormat (Officium Nobile) Dalam Sistem Negara Hukum Di Indonesia," Khazanah: Jurnal Studi Islam dan Humaniora 13, no. 1 (2015).
Pemberantasan Tindak Pidana Korupsi adalah: ${ }^{3}$

Setiap orang yang secara melawan hukum melakukan perbuatan memperkaya diri sendiri atau orang lain atau suatu korporasi yang dapat merugikan keuangan negara atau perekonomian negara, dipidana penjara dengan penjara seumur hidup atau pidana penjara paling singkat 4 (empat) tahun dan paling lama 20 (dua puluh) tahun dan denda paling sedikit Rp. 200.000.000,00 (dua ratus juta rupiah) dan paling banyak Rp. 1000.000,00 (satu milyar rupiah).

Selanjutnya, ketentuan Pasal 3 UU Nomor 20 Tahun 2001 tentang Pemberantasan Tindak Pidana Korupsi menyebutkan bahwa: ${ }^{4}$

Setiap orang yang dengan tujuan menguntungkan diri sendiri atau orang lain atau suatu korporasi, menyalahgunakan kewenangan, kesempatan atau sarana, yang ada padanya karena jabatan atau kedudukan yang dapat merugikan keuangan negara atau perekonomian negara, dipidana dengan pidana penjara seumur hidup atau pidana penjara paling singkat 1 (satu) tahun dan paling lama 20 (dua puluh) tahun dan atau denda paling sedikit Rp. 50.000.000,00

3 Undang-Undang Nomor 20 Tahun 2001 tentang Pemberantasan Tindak Pidana Korupsi.

${ }^{4}$ Ibid. 
(lima puluh juta rupiah) dan paling banyak Rp. 1.000.000.000,00 (satu milyar rupiah).

Mahkamah Kostitusi dalam
amar putusannya menyebutkan,
mengadili:

1. Mengabulkan permohonan para Pemohon untuk sebagian;

2. Menyatakan kata "dapat" dalam pasal 2 ayat (1) dan Pasal 3 UndangUndang Nomor 31 Tahun 1999 tentang Pemberantasan Tindak Pidana Korupsi sebagaimana diubah dengan Undang-Undang Nomor 20 Tahun 2001 tentang Perubahan Atas Undang-Undang Nomor 31 tahun 1999 tentang Pemberantasan Tindak Pidana Korupsi (Lembaran Negara Republik Indonesia Tahun 2001 Nomor 134, Tambahan Lembaran Negara Republik Indonesia Nomor 4150) bertentangan dengan UndangUndang Dasar Negara Republik Indonesia Tahun 1945 dan tidak mempunyai kekuatan bukum mengikat.

3. Menolak permohonan para Pemohon untuk selain dan selebihnya;

4. Memerintahkan pemuatan Putusan ini dalam Berita Negara Republik Indonesia sebagaimana mestinya.

\section{Rumusan Masalah}

Berdasarkan uraian tersebut di atas maka penelitian ini menitikberatkan terhadap Putusan Mahkamah Konstitusi Nomor 25/PUU-XIV/2016 terkait dengan proses penegakkan hukum dan pemberantasan tindak pidana korupsi serta implikasi yang mungkin dapat ditimbulkan. Rumusan masalah dalam penelitian ini adalah bagaimana pertimbangan hukum Majelis Hakim Mahkamah Konstitusi dalam Putusan Mahkamah Konstitusi Nomor 25/PUU-XIV/2016 dan implikasi hukum apa yang dapat timbul terkait dengan proses penegakan hukum dan pemberantasan tindak pidana korupsi.

\section{Tujuan Penelitian}

1. Mengetahui pertimbangan hukum Majelis Hakim Mahkamah Konstitusi dalam Putusan Mahkamah Konstitusi Nomor 25/PUU-XIV/2016, dan

2. Mengetahui Implikasi hukum apa yang dapat timbul terkait dengan proses penegakan hukum dan pemberantasan tindak pidana korupsi. 
Metode Penelitian

Metode penelitian yang digunakan dalam penelitian ini adalah yuridis normatif, yaitu penelitian yang dalam pengkajiannya dengan mengacu dan mendasarkan pada norma-norma dan kaidah-kaidah hukum, peraturan perundang-undangan yang berlaku, teori-teori dan doktrin hukum, yurisprudensi, dan bahan-bahan kepustakaan lainnya yang relevan dengan topik penelitian.

Pengumpulan bahan hukum dilakukan dengan studi pustaka yakni melalui pengkajian terhadap, UUD NRI Tahun 1945, Undang-Undang Nomor 48 Tahun 2009 tentang Kekuasaan Kehakiman, UndangUndang Republik Indonesia Nomor 4 Tahun 2014 tentang Penetapan Peraturan Pemerintah Pengganti Undang-Undang Nomor 1 Tahun 2013 tentang Perubahan Kedua Atas Undang-Undang Nomor 24 Tahun 2003 tentang Mahkamah Konstitusi, Undang-Undang Nomor 30 Tahun 2004 tentang Administrasi Pemerintahan, Undang-Undang Nomor 20 Tahun 2001 tentang Perubahan Atas Undang-Undang Nomor 31 Tahun 1999 tentang
Pemberantasan Tindak Pidana Korupsi, Undang-Undang Nomor 8 tahun 1981 tentang Kitab UndangUndang Hukum Acara Pidana, Putusan Mahkamah Konstitusi Nomor 25/PUU-XIV/2016, Yurisprudensi Mahkamah Konstitusi, serta berbagai pustaka yang relevan dengan objek penelitian.

Pendekatan yang digunakan dalam penelitian ini adalah pendekatan yuridis, yakni menganalisis permasalahan tentang pertimbangan hukum Majelis Hakim Mahkamah Konstitusi dalam Putusan Mahkamah Konstitusi Nomor 25/PUU-XIV/2016 dan implikasi hukum apa yang dapat timbul terkait dengan proses penegakan hukum dan pemberantasan tindak pidana korupsi.

\section{Hasil Dan Pembahasan}

Pertimbangan Hukum Majelis Hakim Mahkamah Konstitusi dalam Putusan Mahkamah Konstitusi Nomor 25/PUUXIV/2016

Permohonan perkara Nomor 25/PUU-XIV/2016 yang sebagaimana dimaksud dalam penelitian ini adalah diajukan oleh: 
1. Firdaus, S.T., M.T (selanjutnya pada intinya berpendapat sebagai disebut sebagai Pemohon I); berikut:

2. Drs. H. Yulius Nawawi [3.10.4] Bahwa dengan keberadaan UU (selanjutnya disebut sebagai Administrasi Pemerintahan dikaitkan Pemohon II); $\quad$ dengan kata "dapat" dalam Pasal 2 ayat

3. Ir. H. Imam Mardi Nugroho (1) dan ayat (3) UU Tipikor menurut (selanjutnya disebut sebagai Mahkamah menyebabkan terjadinya Pemohon III); pergeseran paradigma penerapan unsur

4. Ir. H. A. Hasdullah, M.Si merugikan keuangan negara dalam (selanjutnya disebut sebagai tindak pidana korupsi. Selama ini, Pemohon IV); berdasarkan Putusan Mahkamah

5. H. Sudarno Eddi, S.H., M.H. Nomor 003/PUU-IV/2006 (selanjutnya disebut sebagai pemahaman kata "dapat" dalam Pasal 2 Pemohon V);

ayat (1) dan Pasal 3 UU Tipikor 6. Jamaludin Masuku, S.H. menyebabkan perbuatan yang akan (selanjutnya disebut sebagai dituntut di depan pengadilan bukan Pemohon VI); saja karena perbuatan tersebut

Mahkamah memeriksa dengan "merugikan keuangan negara atau seksama permohonan dan bukti-bukti perekonomian negara secara nyata" surat/tulisan yang diajukan oleh para akan tetapi hanya "dapat" Pemohon, keterangan ahli dari para menimbulkan kerugian saja pun Pemohon, keterangan Presiden, sebagai kemungkinan atau potential loss, keterangan tertulis Dewan Perwakilan jika unsur perbuatan tindak pidana Rakyat, keterangan dan bukti-bukti korupsi dipenuhi, sudah dapat diajukan surat/tulisan Pihak terkait Dr. Drs. ke depan pengadilan. Dalam Yesaya Buiney, M.M, dan kesimpulan perkembangannya dengan lahirnya UU tertulis para Pemohon, yang Administrasi Pemerintahan maka selengkapnya termuat dalam duduk kerugian negara karena kesalahan perkara, selanjutnya Mahkamah yang administratif bukan merupakan unsur tindak pidana korupsi. Kerugian negara 
menjadi unsur tindak pidana korupsi jika terdapat unsur melawan hukum dan penyalahgunaan kewenangan. Dalam hal adanya penyalahgunaan kewenangan, suatu perbuatan baru dapat diklasifikasikan sebagai tindak pidana korupsi apabila berimplikasi terhadap kerugian negara (kecuali untuk tindak pidana korupsi suap, gratifikasi atau pemerasan), pelaku diuntungkan secara melawan hukum, masyarakat tidak dilayani, dan perbuatan tersebut merupakan tindakan tercela. Dengan demikian bila dikaitkan dengan Pasal 2 ayat (1) dan Pasal 3 UU Tipikor, maka penerapan unsur merugikan keuangan negara telah bergeser dengan menitikberatkan pada adanya akibat, tidak lagi hanya perbuatan. Dengan perkataan lain kerugian negara merupakan implikasi dari : 1) adanya perbuatan melawan hukum yang menguntungkan diri sendiri atau orang lain atau suatu korporasi sebagaimana dimaksud dalam Pasal 2 ayat (1) UU Tipikor dan 2) penyalahgunaan kewenangan dengan tujuan menguntungkan diri sendiri atau orang lain atau suatu korporasi sebagaimana dimaksud dalam Pasal 3
UU Tipikor. Berdasarkan hal tersebut menurut Mahkamah unsur merugikan keuangan negara tidak lagi dipahami sebagai perkiraan (potential loss) namun harus dipahami benar-benar sudah terjadi atau nyata (actual loss) untuk dapat diterapkan dalam tindak pidana korupsi.

[3.10.5] Bahwa pencantuman kata "dapat" dalam Pasal 2 ayat (1) dan Pasal 3 UU Tipikor membuat delik dalam kedua pasal tersebut menjadi delik formil. Hal itu menurut Mahkamah dalam praktik seringkali disalahgunakan untuk menjangkau banyak perbuatan yang diduga merugikan keuangan negara, termasuk terhadap kebijakan atau keputusan diskresi atau pelaksanaan asas freies Ermessen yang diambil bersifat mendesak dan belum ditemukan landasan hukumnya, sehingga seringkali terjadi kriminalisasi dengan dugaan terjadinya penyalahgunaan wewenang. Demikian juga terhadap kebijakan yang terkait dengn bisnis namun dipandang dapat merugikan keuangan negara maka dengan pemahaman kedua pasal tersebut sebagai delik formil seringkali 
dikenakan tindak pidana korupsi. sebagaimana ditentukan dalam Pasal Kondisi tersebut tentu dapat 28G ayat (1) UUD NRI Tahun 1945. menyebabkan pejabat publik takut Selain itu, menurut Mahkamah kata mengambil suatu kebijakan atau "dapat" dalam Pasal 2 ayat (1) dan khawatir kebijakan yang diambil akan Pasal 3 UU Tipikor juga bertentangan dikenakan tindak pidana korupsi, dengan prinsip perumusan tindak sehingga di antaranya akan berdampak pidana yang harus memenuhi prinsip pada stagnasi proses penyelenggaraan hukum harus tertulis (lex scripta), harus negara, rendahnya penyerapan ditafsirkan seperti yang dibaca (lex anggaran, dan terganggunya stricta), dan tidak multitafsir (lex certa), pertumbuhan investasi. Kriminalisasi oleh karenanya bertentangan dengan kebijakan terjadi karena terdapat prinsip negara hukum sebagaimana perbedaan pemaknaan kata "dapat" ditentukan dalam Pasal 1 ayat (3) UUD dalam unsur merugikan keuangan NRI Tahun 1945.

negara dalam tindak pidana korupsi Didalam Putusan Mahkamah dalam oleh aparat penegak hukum, sehingga perkara a quo, terdapat dissenting opinion seringkali menimbulkan persoalan (beda pendapat) yaitu oleh I Dewa mulai dari perhitungan jumlah kerugian Gede Palguna, Suhartoyo, Aswanto, negara yang sesungguhnya sampai Maria Farida Indrati. Dissenting opinion kepada lembaga manakah yang (beda pendapat) tersebut yang pada berwenang menghitung kerugian intinya adalah:

negara. Oleh karena dipraktikkan Keberadaan frasa kata "dapat" secara berbeda-beda menurut dalam Pasal 2 ayat (1) dan Pasal 3 Mahkamah pencantuman kata "dapat" Undang-Undang Tipikor tidak dalam Pasal 2 ayat (1) dan Pasal 3 UU bertentangan dengan kepastian hukum Tipikor menimbulkan ketidakpastian sebagaimana didalilkan para Pemohon. hukum dan telah secara nyata Berkenaan dengan kata "dapat" bertentangan dengan jaminan bahwa tersebut dalam Penjelasan Pasal 2 ayat setiap orang berhak atas rasa aman dan (1) Undang-Undang Tipikor dikatakan, perlindungan dari ancaman ketakutan antara lain, “... Dalam ketentuan ini, 
kata "dapat" sebelum frasa "merugikan keuangan negara atau perekonomian negara" menunjukkan bahwa tindak pidana korupsi merupakan delik formil, yaitu adanya tindak pidana korupsi cukup dengan dipenuhinya unsurunsur perbuatan yang sudah dirumuskan bukan dengan timbulnya akibat". Sementara itu, dalam Penjelasan Pasal 3 Undang-Undang Tipikor dikatakan, kata "dapat" dalam ketentuan ini diartikan sama dengan Penjelasan Pasal 2". Dengan demikian menghilangkan kata "dapat" dari rumusan kedua norma pasal tersebut akan mengubah secara mendasar kualifikasi delik dari tindak pidana korupsi, dari formil menjadi delik materiil. Konsekuensiny, jika akibat yang dilarang, yaitu "merugikan keuangan negara atau perekonomian negara" belum atau tidak terjadi meskipun unsur "secara melawan hukum" dan unsur "memperkaya diri sendiri atau orang lain atau suatu korporasi” telah terpenuhi, maka berarti belum terjadi tindak pidana korupsi.

Hingga saat ini, tidak terdapat perubahan mendasar dalam pandangan akademik berkenaan dengan nature perbuatan korupsi yang apabila dibiarkan mengakar kuat dalam skala besar sesungguhnya ia bukan hanya telah bermetamorfosis menjadi kejahatan luar biasa (extraordinary crime) melainkan juga dapat diposisikan sebagai hostis bumani generis, musuh bersama umat manusia, mengingat proliferasinya yang idak memandang negara, baik negara maju maupun negara berkembang, dan daya rusaknya terhadap mentalitas manusia serta terhadap kemampuan negara dalam menunaikan kewajiban konstitusionalnya bagi pemenuhan hak-hak ekonomi dan sosial warganya. Dengan demikian meskipun berdasarkan kaidah penafsiran teleologis atau sosiologis dalam penafsiran hukum pada umumnya dan penafsiran konstitusi pada khususnya tersedia justifikasi bagi Mahkamah untuk mengubah pendiriannya, kami berpendapat dalam konteks persoalan $a$ quo tidak terdapat alasan mendasar dalam kondisi empirik-sosiologis yang secara rasional dapat digunakan sebagai alasan kuat bagi Mahkamah sehingga perlu meninggalkan pendiriannya 
sebagaimana dinyatakan dalam Putusan diatas.

Berkaitan dengan UndangUndang Nomor 30 tahun 2004 tentang Administrasi Pemerintahan

Administrasi Pemerintahan) kekhawatiran bahwa adanya frasa kata "dapat" dalam Pasal 2 ayat (1) dan Pasal 3 UU Tipikor berpotensi menjadikan seorang pejabat pemerintah, termasuk para Pemohon dapat dijatuhi pidana tanpa adanya kesalahan yang berupa kerugian negara, menurut Hakim dissenting opinion tidaklah beralasan. UU Administrasi Pemerintahan telah memberikan perlindungan terhadap pejabat pemerintah apabila yang bersangkutan diduga melakukan penyalahgunaan wewenang yang merugikan keuangan negara. Sebab, menurut UndangUndang a quo terhadap adanya dugaan penyalahgunaan wewenang dapat dilakukan mekanisme pengujian melalui Pengadilan Tata Usaha Negara, sedangkan ada atau tidaknya penyalahgunaan wewenang yang diduga menimbulkan kerugian negara, hal tersebut akan diputuskan berdasarkan hasil pengawasan aparat intern pemerintah [vide Pasal 19 dan Pasal 20 UU Administrasi Pemerintahan]. Ketentuan demikian jelas merupakan penegasan akan adanya bentuk perlindungan terhadap pejabat pemerintah karena dengan adanya mekanisme tersebut aparat penegak hukum tidak serta merta dapat mendalilkan adanya penyalahgunaan wewenang oleh pejabat pemerintah, termasuk ada atau tidaknya kerugian negara.

Implikasi Hukum Pasca Putusan Mahkamah Konstitusi Nomor 25/Puu-XIV/2016 Terkait dengan Proses Penegakan Hukum dan Pemberantasan Tindak Pidana Korupsi di Indonesia

Pasca putusan Mahkamah Konstitusi Nomor: 25/PUUXIV/2016 dimana menyatakan bahwa frasa kata "dapat" dalam rumusan Pasal 2 dan Pasal 3 Undang-Undang tentang Tindak Pidana Korupsi bertentangan dengan konstitusi sehingga "tidak mengikatnya" kata "dapat" menjadikan ketentuan Pasal 2 dan Pasal 3 Undang-Undang tentang Tindak Pidana Korupsi menjadi delik 
materiil, dimana sebelumnya ketentuan Pasal tersebut adalah delik formil.

P.A.F Lamintang memberikan pengertian bahwa: ${ }^{5}$

1. Tindak pidana materiil adalah tindak pidana yang dianggap telah selesai dengan ditimbulkannya akibat yang dilarang dan diancam dengan hukuman oleh undang-undang;

2. Tindak pidana formil adalah tindak pidana yang dianggap telah selesai dengan hukuman oleh undang-undang.

Adapun menurut Sudarto memberikan pengertian: ${ }^{6}$

a. Tindak pidana materiil adalah tindak pidana yang perumusannya dititikberatkan pada akibat yang tidak diketahui (dilarang), tindak pidana ini baru dianggap selesai apabila akibat yang tidak dikehendaki (dilarang) tersebut benar-benar terjadi;

5 P.A.F Lamintang, 1997, Dasar-dasar Hukum Pidana Indonesia, Bandung: PT Citra Aditya Bhakti.

${ }^{6}$ Sudarto, 1989, Hukum dan Hukum Pidana, Bandung: Alumni. b. Tindak pidana formil adalah merupakan tindak pidana yang perumusannya dititik beratkan pada perbuatan yang dilarang, tindak pidana tersebut selesai dengan dilakukannya perbuatan yang telah dirumuskan tanpa melihat akibatnya.

Memahami konstruksi dasar Pasal 2 ayat (1) dan Pasal 3 UU Tindak Pidana Korupsi maka secara gramatikal kedua Pasal tersebut menganut delik formil yang membawa konsekuensi bahwa seseorang dianggap sebagai tersangka apabila sudah menyelesaikan rangkaian perbuatan sebagaimana yang dimaksudkan dalam ketentuan Pasal 2 ayat (1) dan Pasal 3 Undang-Undang Tindak Pidana Korupsi. Sehingga frasa kata "dapat" memberikan arti bahwa akibat "merugikan negara atau perekonomian negara" tidak harus benar-benar terjadi, yang penting (rangkaian) perbuatan pelaku sudah sesuai dengan rumusan delik ditambah dengan perbuatan tersebut memiliki peluang merugikan keuangan negara atau perekonomian negara.

Penjelasan Pasal 2 ayat (1) dan Pasal 3 Undang-Undang Tindak Pidana 
Korupsi mengandung makna bahwa sinkronisasi dan harmonisasi antar pembentuk Undang-Undang Tindak instrumen hukum dan peraturan Pidana Korupsi berpendapat tindak perundang-undangan yang lain yaitu pidana korupsi cukup dipenuhinya dengan Undang-Undang Nomor 30 unsur-unsur perbuatan yang Tahun 2004 tentang Administrasi dirumuskan, bukan pada akibat yang Pemerintahan.

ditimbulkannya sehingga tidak perlu Berkaitan dengan sinkronisasi adanya pembuktian dengan adanya hukum nasional, Putusan Mahkamah kerugian negara secara riil (actual loss). Konstitusi Nomor: 25/ PUU-

Merujuk pada apa yang telah XIV/2016 ini juga akan mengubah diuraikan diatas maka dapat dimaknai sistem penegakan hukum tentang bahwa perumusan delik pada ketentuan tindak pidana korupsi yang selama ini Pasal 2 dan Pasal 3 Undang-Undang dilakukan oleh aparat penegak hukum. tentang Tindak Pidana Korupsi Frasa kata "dapat" yang harus mengalami perubahan yang cukup dibuktikan dengan nilai kerugian signifikan dimana perbuatan tindak negara atau perekonomian negara yang pidana Pasca Putusan Mahkamah secara nyata (actual loss) akan Konstitusi Nomor: 25/PUU- berdampak pada lambatnya jalan XIV/2016 korupsi haruslah dapat penegakan hukum, mengingat pula dihitung secara pasti dan nyata berapa bahwa kewenangan lembaga negara nilai kerugian negara (actual loss), yang bisa membuktian nilai kerugian bukanlah nilai kerugian yang hanya negara yang riil ini pun masih terdapat berdasarkan kecurigaan, perkiraan dan tumpang tindih. Putusan Mahkamah potensi (potential loss). Dalam Konstitusi Nomor: 31/PUU-X/2012 pertimbangannya Mahkamah menyebutkan bahwa penyidik korupsi Konstitusi berpendapat bahwa berhak melakukan koordinasi dengan penggunaan konsepsi actual loss lebih lembaga apa pun, termasuk Badan memberikan kepastian hukum yang Pemeriksa Keuangan (BPK), Badan berdasarkan pada nilai-nilai keadilan Pengawas Keuangan dan serta juga bersesuaian dengan upaya Pembangunan (BPKP), atau lembaga 
lain yang punya kemampuan menentukan nilai kerugian negara.

Namun, hal berbeda sebagaimana dalam Surat Edaran Mahkamah Agung Nomor 4 tahun 2016 tentang Pemberlakuan Rumusan Hasil Rapat Pleno Kamar MA tahun 2016, dimana dijelaskan bahwa pada bagian huruf $A$ angka 6 bahwa instansi yang berwenang untuk menilai, menyatakan ada tidaknya nilai kerugian negara adalah Badan Pemeriksa Keuangan (BPK) yang memiliki kewenangan konstitusional. Artinya bahwa badan-badan audit selain Badan Pemeriksa Keuangan (BPK) tidak berwenang untuk menyatakan ada tidaknya kerugian negara.

Dasar yang menjadi alasan Pemohon dalam perkara a quo bahwa kriminalisasi tercipta karena aparat penegak hukum banyak mendakwa Aparatur Sipil Negara (ASN) karena dianggap mengeluarkan kebijakan yang merugikan keuangan negara. Pemaknaan dari hal tersebut haruslah dapat dibedakan antara tindakan murni penegakan hukum dengan penyalahgunaan wewenang. Tindakan penegakan hukum terhadap ASN merupakan tindakan murni penegakan hukum yang dilakukan semata-mata untuk kemajuan lembaga/instansi demi menjaga tidak terjadinya penyimpangan keuangan negara dimana hal ini menjadi tanggung jawabnya untuk mengelola.

\section{Indra Prawira ${ }^{7}$ berpendapat} bahwa penyalahgunaan wewenang bisa terjadi karena 3 (tiga) hal yaitu sumber wewenang, substansi wewenang, dan asas kebebasan bertindak (freis ermessen). Apabila berkaitan adanya kesalahan administratif karena sumber wewenang dan substansi wewenangnya dalam mengeluarkan suatu kebijakan maka dapat menggunakan pendekatan administratif sebagaimana yang telah tertuang dalam Undang-Undang Administrasi Pemerintahan yang nantinya akan dibatalkan atau tidaknya oleh putusan Pengadilan Tata Usaha Negara (PTUN) dimana ini

\footnotetext{
7 Lihat Fathudin, 2015, Tindak Pidana Korupsi (Dugaan Penyalahgunaan Wewenang) Pejabat Publike (Perspektif Undang-Undang Nomor 30 Tabun 2014 tentang Administrasi Pemerintahan), Jurnal Cita Hukum. Vol. II No. 1, Juni 2015, hlm.126. Dalam Fatkhurohman dan Nalom Kurniawan, Pergeseran Delik Korupsi dalam Putusan Mabkamah Konstitusi Nomor 25/PUUXIV/2016 The Shifting of The Corruption Offense on Constitutional Court Decision Number 25/PUU-XIV/2016, Jurnal Konstitusi, Volume 14, Nomor 1, Maret 2017, hlm. 15.
} 
berdasarkan asas legalitas (peraturan wewenang, secara umum cenderung perundang-undangan). Sementara bisa saja terdapat unsur kesalahan atau untuk kebebasan bertindak (freiss bisa juga tidak. Kalaupun terdapat ermessen) merupakan keistimewaan dari kesalahan, belum tentu ada niat untuk pengambil kebijakan jika suatu norma memperkaya dirinya atau orang lain hukum ternyata belum mengatur atau atau suatu korporasi untuk merugikan tidak jelasnya aturan, sehingga boleh keuangan negara.

mengeluarkan suatu kebijakan atau disebut juga wewenang bebas atau diskresi. ${ }^{8}$

Kedua, unsur akibat dari perbuatan (actus reus) . Perbuatan melawan hukum memiliki Beranjak dari hal tersebut kecenderungan terdapat akibat maka perlu dipahami tentang kerugian bagi pihak lain, dalam konteks perbuatan melawan hukum dan ini terjadinya kerugian keuangan penyalahgunaan wewenang. negara. Sementara penyalahgunaan Sebagaimana yang telah disebutkan wewenang, cenderung mengarah dalam ketentuan Pasal 2 ayat (1) dan kepada kerugian yang bersifat personal Pasal 3 dengan Pasal 20 ayat (4) dengan kategori pelanggaran yang Undang-Undang Tindak Pidana bersifat administratif. Sehingga frasa Korupsi dan Pasal 70 ayat (3) Undang- kata "dapat" dalam pasal 2 ayat (1) dan Undang Administrasi Pemerintahan, Pasal 3 Undang-Undang Tindak Pidana yaitu pertama, aspek niat (mens rea) yang Korupsi sungguh tidak tepat jika materi tentu saja berbeda antara keduanya. muatannya dimasukkan penafsirannya Perbuatan melawan hukum dapat ke dalam Undang-Undang dipastikan terdapat unsur kesalahan Administrasi Pemerintah. Konstruksi dalam diri seseorang yang memang pemikiran dari unsur filosofis, yuridis, memiliki niat untuk memperkaya diri dan sosiologis antara keduanya sendiri atau orang lain atau korporasi mempunyai makna yang berbeda untuk merugikan keuangan negara. sehingga di antara keduanya tidak Sementara dalam penyalahgunaan memiliki hubungan karena antara 
keduanya berangkat dari prinsip hukum yang tidak sama.

Catatan kinerja Komisi Pemberantasan Korupsi (KPK) sebagaimana yang disampaikan oleh Wakil Ketua KPK Basaria Panjaitan bahwa selama 2017 lembaganya telah melakukan 114 kegiatan penyelidikan kasus korupsi, kemudian 118 penyidikan kasus dan 94 kegiatan penuntutan perkara korupsi, selain itu melakukan eksekusi terhadap 76 putusan pengadilan yang telah berkekuatan hukum tetap. ${ }^{9}$ Catatan akhir tahun 2017 yang dirilis KPK menyimpulkan kasus suap tetap mendominasi perkara korupsi yang ditangani. Tercatat, ada 93 perkara suap yang ditangani KPK di tahun 2017, dimana jumlah ini meningkat dari 79 kasus di tahun 2016. ${ }^{10}$

Terkait dengan data diatas dimana dominasi perkara tindak pidana korupsi masih dipegang oleh kasus suap. Sehingga penanganan tindak pidana korupsi oleh KPK sejak keluarnya Putusan Mahkamah

\footnotetext{
9 https://www.kpk.go.id/id/...kpk.../4140kpk-lakukan-19-kali -ott-sepanjang-tahun2017. Diakses pada tanggal 03 Maret 2018. 10 https:/ / tirto.id. Diakses tanggal 03 Maret 2018.
}

Konstitusi Nomor: 25/PUUXIV/2016 banyak dinilai baik dari kalangan publik, akademisi hingga kalangan praktisi akan mengalami kesulitan dalam perjalanannya. Hal ini disebabkan karena dalam prakteknya sering kali jumlah kerugian negara dapat terus bertambah seiring dengan pengembangan kasus. Dalam hal ini penegak hukum akan dapat dipastikan mengalami kesulitan untuk menjadikan seseorang menjadi tersangka jika kerugian negara tidak boleh lagi bersifat potensi (potential loss) atau taksiran keuangan negara yang belum riil (actual loss).

\section{Penutup dan Simpulan}

Adanya Putusan Mahkamah Konstitusi Nomor 25/PUU-XIV/2016 melahirkan ketidakpastian hukum yaitu berkaitan dengan rumusan delik tindak pidana korupsi, dimana awalnya rumusan tindak pidana korupsi adalah delik formil menjadi delik materiil. Hal ini akan dapat menyebabkan adanya perubahan dalam penegakan hukum, yaitu penegak hukum harus dapat membuktikan berapa nilai kerugian keuangan negara atau perekonomian negara secara riil atau nyata (actual loss) 
bukan pada sudut pandang potensi nilai kerugian yang akan dialami (potential loss). Dampak dari hal tersebut maka dalam upaya pemberantasan hukum akan memunculkan disharmonisasi antara hukum pemberantasan korupsi untuk menentukan lembaga yang mempunyai kewenangan menilai kerugian negara atau perekonomian negara.

Frasa kata "dapat" merugikan keuangan negara atau perekonomian negara antara pendekatan pidana sebagaimana dalam Undang-Undang Tindak Pidana Korupsi dengan pendekatan administratif sebagaimana dalam Undang-Undang Nomor 30 Tahun 2004 adalah 2 hal yang berbeda dan tidak mempunyai hubungan hukum. Merujuk pada hal mendasar dari perbuatan melawan hukum dengan penyalahgunaan wewenang dalam kesalahan administrasi, merumuskan adanya sebab atau niat batin (mens rea) dan akibat atau hasil perbuatan (actus reus) yang berbeda. Begitu pula dengan upaya kriminalisasi terhadap ASN yang menjadikan dasar atau alasan pemohon dalam perkara a quo, dimana hal ini tidak mempunyai implikasi hukum terhadap pemaknaan frasa kata "dapat" merugikan keuangan negara atau perekonomian negara. Karena kebijakan hukum diskresi (freiss ermessen) dapat digunakan selama itu tidak keluar dari Asas-Asas Umum Pemerintahan Yang Baik (AUPB). Penyalahgunaan wewenang dapat tercipta tergantung pada sudut pandang niat batin (mens rea) untuk berbuat jahat sehingga dapat memperkaya diri sendiri, orang lain atau korporasi.

Berdasarkan pada penjelasan diatas maka Peneliti berpendapat bahwa perlu adanya ketegasan dalam menentukan rumusan delik dalam Undang-Undang Tindak Pidana Korupsi demi terlaksananya dan tegaknya Hukum Acara Pidana dan Administrasi sehingga para aparat penegak hukum akan mampu mengambil langkah dalam upaya penegakan hukum terhadap tindak pidana korupsi. Merekonstruksi kembali peraturan perudang-undangan yang berkaitan dengan lembagalembaga yang mempunyai kewenangan untuk menilai kerugian negara atau perekonomian negara agar supaya tercipta sinkronisasi dan harmonisasi 
antar peraturan perundang-undangan. Kemudian membentuk aturan baru tentang alur penanganan tindak pidana korupsi agar supaya terlihat jelas pemisahan antara pendekatan secara administratif dengan rumusan pidana. Sehingga tidak ada lagi pemikiran tentang upaya-upaya kriminalisasi terhadap ASN, dan yang paling penting adalah supaya pemberantasan tindak pidana dapat berjalan secara maksimal.

\section{Daftar Pustaka}

\section{Buku}

Fetterman, David M. 1998. Ethnography Step by Step, London: Sage Publishing.

Hafidzi, Anwar. "Eksistensi Advokat Sebagai Profesi Terhormat (Officium Nobile) Dalam Sistem Negara Hukum Di Indonesia." Khazanab: Jurnal Studi Islam dan Humaniora 13, no. 1 (2015).

Hamzah, Andi. 1991. Korupsi Di Indonesia Masalab dan Pemecahannya, Jakarta: Gramedia Pustaka Utama.

Hanitijo, Soemitro Ronny. 1988. Metodologi Penelitian Hukum dan Jurimetri, Jakarta: Ghalia Indonesia.

1991. dan Jurimetri, Jakarta: Ghalia Indonesia.

Hartanti, Evi. 2005. Tindak Pidana Korupsi, Jakarta: Sinar Grafika.

Lamintang, P.A.F. 1997. Dasar-dasar Hukum Pidana Indonesia, Bandung: PT Citra Aditya Bhakti.

Marzuki, Peter Mahmud. 2011. Penelitian Hukum, Cetakan Ketujuh, Jakarta: Kencana.

Prasetyo, Teguh dan Abdul Hakim Barkatullah. 2005. Politik Hukum Pidana Kajian Kebijakan Kriminalisasai dan Deskriminalisasi, Yogyakarta: Pustaka Pelajar.

Prinst, Darwan. 2002. Pemberantasan Tindak Pidana Korupsi, Bandung: PT. Citra Aditya Bakti.

Soekanto, Soerjono dan Sri Mamudji. 2009. Penelitian Hukum Normatif Suatu Tinjauan Singkat, Cetakan ke-11, Jakarta: PT Raja Grafindo Persada.

Sudarto. 1989. Hukum dan Hukum Pidana, Bandung: Alumni.

Sutendi, Adrian. 2010. Hukum Keuangan Negara, Jakarta: Sinar Grafika.

\section{Undang-Undang dan Putusan}

Mahkamah Konstitusi 
Undang-Undang Dasar NRI Tabun 1945 Dalam Satu Naskah, 2006, Jakarta: PT. Citra Umbara.

Undang-Undang Nomor 8 tahun 1981 tentang Kitab UndangUndang Hukum Acara Pidana.

Undang-Undang Nomor 20 Tahun 2001 Tentang Perubahan Atas Undang-Undang Nomor 31 Tahun 1999 Tentang Pemberantasan Tindak Pidana Korupsi.

Undang-Undang Nomor 30 Tahun 2004 tentang Administrasi Pemerintahan.

Undang-Undang Nomor 48 Tahun

2009 Tentang Kekuasaan Kehakiman.

Undang-Undang Republik Indonesia Nomor 4 Tahun 2014 Tentang Penetapan Peraturan Pemerintah Pengganti Undang-Undang Nomor 1 Tahun 2013 tentang Perubahan Kedua Atas Undang-Undang Nomor 24 Tahun 2003 tentang Mahkamah Konstitusi.

Putusan Mahkamah Konstitusi Nomor 25/PUU-XIV/2016.

\section{Makalah}

Fathudin, 2015, Tindak Pidana Korupsi (Dugaan Penyalahgunaan Wewenang) Pejabat Publik Perspektif Undang-Undang Nomor 30 Tabun 2014

\author{
tentang Administrasi \\ Pemerintahan), Jurnal Cita \\ Hukum. Vol. II No. 1, Juni \\ 2015.
}

Fatkhurohman dan Nalom Kurniawan, Pergeseran Delik Korupsi dalam Putusan Mabkamah Konstitusi Nomor 25/PUUXIV/2016 The Shifting of The Corruption Offense on Constitutional Court Decision Number 25/PUUXIV/2016, Jurnal Konstitusi, Volume 14, Nomor 1, Maret 2017.

Hanitijo, Ronny Soemitro, 2001,Suplemen Baban Kuliah Metodologi Penelitian Hukum, Bahan Kuliah Metodologi Penelitian Hukum pada Program Pasca Sarjana Magister Ilmu Hukum UNDIP.

Mahendra, Yusril Ihza, 1995, Dekrit Presiden 5 Juli 1959 dan Implikasinya terbadap Perumusan Politik Hukum Nasional, makalah disampaikan pada seminar sehari Menyongsong Hari Kemerdekaan RI ke 50, tanggal 5 Agustus 1995 yang diselenggarakan oleh ICMI Korwil DKI Jakarta.

\section{Website}

$$
\begin{gathered}
\text { https://www.kpk.go.id/id/...kpk.../41 } \\
\text { 40-kpk-lakukan-19-kali - } \\
\text { ott-sepanjang-tahun-2017. }
\end{gathered}
$$

https:/ / tirto.id. 
Dadin, Implikasi Hukum Atas Putusan Mabkamah Konstitusi 19 